\title{
Düzce İlinde İlkokulların İç ve Dış Ortamlarındaki Toz Örneklerinde PCB Düzeylerinin Belirlenmesi
}

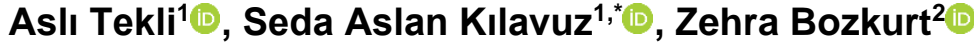 \\ ${ }^{1}$ Kocaeli Üniversitesi Mühendislik Fakültesi Çevre Mühendisliği Bölümü, 41001, Kocaeli. \\ ${ }^{2}$ Düzce Üniversitesi, Mühendislik Fakültesi, Çevre Mühendisliği Bölümü, 81620, Düzce.
}

\section{Özet}

Sanayi, trafik ve konut bölgelerinin iç içe geçtiği Düzce ili hızla gelişmekte ve bu nedenle bölgede çevresel kirlilik yoğun olarak hissedilmektedir. Emisyon kaynaklarından çıkan hava kirleticileri ilin coğrafi konumu sebebi dağılamamakta ve önemli sağllk riskleri oluşturmaktadır. Bu çalışmada bölgesel kirlilik dağılımı ve çeşitli emisyon kaynaklarını açıklayabilmek için farklı konumlarda toz örnekleri toplanmıştır. Çocuklar hava kirleticileri açısından daha hassas risk grubunda yer alması nedeniyle örneklemeler için ilkokulların iç ve dış ortamları seçilmiştir. Toplanan toz örneklerinde PCB düzeyleri belirlenmiştir. Mekanik süpürme tekniği kullanılarak toplanan örneklerde PCB analizleri Gaz Kromatografisi/Kütle Spektrometresi (GC/MS) cihazı kullanılarak gerçekleştirilmiştir. Elde edilen sonuçlarda dış ortam $\Sigma P C B$ konsantrasyonları 0,737-22,307 $\mathrm{ng} / \mathrm{gr}$ arasında olup, ortalama 3,626 $\mathrm{ng} / \mathrm{gr}$ olarak bulunmuştur. İç ortam $\Sigma P C B$ konsantrasyonlart ise 17,17-294,22 ng/gr arasinda olup, ortalama 66,89 $\mathrm{ng} / \mathrm{gr}$ olarak bulunmuştur. İç ortam örneklerinde yüksek $\sum P C B$ konsantrasyonları, iç ortam kaynaklarının katkısının ve dış ortamdan taşınım yolu ile iç ortamlarda gerçekleşen birikimin etkisinin daha fazla olduğunu göstermektedir. Dış ortam kaynaklarına göre yapılan değerlendirmede en yüksek konsantrasyonlar daha çok endüstriye yakın noktalarda elde edilmiştir. En düşük konsantrasyonlar ise kırsal örnekleme noktalarında ölçülmüștür.

\section{$\underline{\text { Anahtar Sözcükler }}$}

Düzce, Toz, PCB, Kirlilik Dağılım Haritaları

\section{Determination of PCB Levels Indoor and Outdoor Dust Samples of Primary Schools in Düzce}

\begin{abstract}
Düzce province, where industry, traffic and residential areas are intertwined, is developing rapidly and therefore environmental pollution is intensely felt in the region. Air pollutants from emission sources cannot be dispersed due to the geographical location of the province and pose important health risks. In this study, dust samples were collected at different locations in order to explain the regional pollution distribution and various emission sources. Because children are more sensitive to air pollutants, indoor and outdoor environments of primary schools were selected for sampling. PCB levels were determined in dust samples collected from indoor and outdoor environments of the primary schools in Düzce. PCB analyses were performed by using the Gas chromatograph/Mass Spectrometer $(G C / M S)$ instrument. In the obtained results, outdoor $\Sigma P C B$ concentrations were between 0.737 and $22.307 \mathrm{ng} / \mathrm{gr}$, with an average of 3,626 $\mathrm{ng} / \mathrm{gr}$. Indoor $\Sigma P C B$ concentrations were between 17.17 and $294.22 \mathrm{ng} / \mathrm{gr}$, with an average of $66.89 \mathrm{ng} / \mathrm{gr}$. High $\Sigma P C B$ concentrations in indoor samples show that the contribution of indoor sources and the effect of accumulation in indoor environments by transport from the outdoor environments is greater. In the evaluation made according to outdoor sources, the highest concentrations were obtained mostly at points close to the industrial area. The lowest concentrations were measured at rural sampling points.
\end{abstract}

Keywords

Düzce, Dust, PCB, Pollution Distribution Maps

\section{Giriş}

Günümüzde insanoğlunun sanayileşmeye verdiği önemin artmasıyla birlikte çevre kirliliğinde de kayda değer artışlar yaşanmıştır (Gül vd. 2018). Özellikle endüstri devrimiyle beraber ciddi sağlık sorunlarına yol açan hava kirliliği, gelişen ve gelişmekte olan ülkeler için önemli çevre sorunlarından biri haline gelmiştir (Bayram ve Dikensoy 2006). Hava kirliliği hava bileşimini değiştiren katı, sıvı ve gaz halde bulunabilen kirleticilerin, insan sağlığına, canlı hayatına ve ekolojik dengeye zarar verecek miktar veya sürede atmosferde bulunması olarak tanımlanabilir. Hava kirliliğini dış ortam ve iç ortam hava kirliliği olmak üzere iki kısma ayırmak mümkündür. Bulunulan ortam (iç veya dış) havasında hava kirleticilerinin miktarının artması, ortamın hava kalitesini azaltmaktadır (Cuci ve Polat 2015). 
İnsanlar zamanlarının çoğunu iç ortamlarda geçirmektedirler. Bu nedenle özellikle çocuklar ve yaşlilar için iç ortam kirleticilerine maruziyetle ilgili çalışmalar önem kazanmaktadır. İç ortam hava kalitesini dış ortamdan taşınan kirleticilerle birlikte, iç ortama özgü unsurlar da (mobilyalar, pencereler, boya, kalem vb. kullanılan materyaller) etkilemektedir. Bazı durumlarda kümülatif etki nedeniyle iç ortam hava kalitesi dış ortama göre daha kötü olabilmektedir. İç ortam hava kalitesini etkileyen en önemli kirleticiler gaz ve partikül kirleticilerdir. İç ortamdaki partiküller uzun süre kirleticileri depoladıklarından dolayı, gaz kirleticilere göre, insanların kirletici maddelere maruziyetinin tahmin edilmesi için daha uygundur. İç ortam havasında bulunan kirleticiler insan vücuduna soluma, yutma veya deriden direk emilim yoluyla girmektedir. İnsan vücuduna giren özellikle solunabilen partiküller başta akciğer hastalıkları olmak üzere, kirletici türüne göre kanser gibi çok ciddi sağlık problemlerine neden olabilmektedir (Whitehead vd. 2011; Mendell ve Heath 2005).

Genel olarak hava kirliliğinin temel bileşenleri, gaz kirleticiler ve partikül maddeler (uçuşan tozlar, aerosoller) olarak ayrılmış olsa da bir diğer etkenin yatay yüzeylere çökelmiş toz olduğu göz ardı edilmemelidir. Çökelmiş tozlar, dış etmenler ile tekrar havaya karışabilen partikül maddelerdir. Aynı zamanda, havada bulunan inorganik ve organik kirletici maddeler için depo görevi görmektedirler (Sofuoğlu 2016). İç ve diş ortamlarda çeşitli kaynaklardan gelen toz (partikül madde), insan sağlı̆̆ını en çok etkileyen materyaldir (Acosta vd. 2014). Tozlar, ağır metaller, pestisitler, polisiklik aromatik hidrokarbonlar, poli klorlu bifeniller vb. gibi pek çok toksik kimyasalları içerebildiğinden, insan sağlığı üzerinde ciddi olumsuz etkileri vardır. Ayrıca, havaya, suya ve toprağa taşınabilirler, böylece tüm ekosistem tozun taşıdığı kirleticilerden ve bu kirleticilerin birikiminden etkilenebilir (Khairy vd. 2011).

Poliklorlubifeniller (PCB), çevre ortamlarındaki kalıcılıkları ve kanserojen yan ürünlere dönüşebilme potansiyellerinden dolayı hava kirliliğine sebep olan önemli organik bileşiklerdir (Aydın vd. 2015). PCB'ler başlangıçta endüstriyel amaçlarla üretilmiş fakat doğada kalıcı oldukları belirlendikten sonra pek çok ülkede üretimleri yasaklanmıştır. Ancak, PCB içeren kapasitör, trafo, hidrolik pompa, matbaa mürekkebi, boya, pestisit vb. ürünler günümüzde hala kullanıldığg için çevre ve insan sağlığını tehdit etmektedirler (Seyran ve Erişir 2008). PCB'ler iç ortam havasında, dış ortam havasından daha yüksek konsantrasyonlarda tespit edilmiştir. PCB içeren bileşenlere sahip floresan aydınlatma balastları gibi bazı elektrikli cihazların, iç ortam havasına PCB yayabileceği ileri sürülmüştür. Ayrıca PCB'ler, \% 30'a kadar PCB içerebilen derz dolgu macunlarında plastikleştirici olarak kullanılmıştır. PCB'ler coğrafi olarak geniş bir alana yayılırlar ve tıpkı PAH'lar gibi canlı organizmaların yağ dokusunda birikerek insanlar ve doğal yaşam için toksik özellik göstermektedirler (Barro vd. 2009).

Bireylerin yetiştirilmesinde büyük rolü olan okullar yaşamımızın merkezi konumundadırlar (Öztürk ve Düzovalı 2011). Çağımızın en büyük sorunlarından biri olan hava kirliliği okullardaki personel ve öğrencilerin sağlık ve verimliliğini olumsuz yönde etkilemektedir. Bu etkiler hafif rahatsızlık veren belirtilerden ciddi ve sürekli rahatsızlıkların ortaya çıkmasına kadar uzanabilmektedir. İlköğretim yaşlarında olan çocuklarda, kirleticilerden kaynaklanan sağlık etkileri yetişkinlere göre daha fazla görülmektedir. Bu nedenle çocuklar, toplum içerisinde hassas alt gruplar arasında yer almaktadırlar (Sofuoğlu 2016). Son zamanlarda yapılan pek çok çalışmada, okullardaki hava kirliliğine maruz kalan çocuklarda istenmeyen sağllk etkileri gözlemlenmiştir. Hava kirliliğinin potansiyel etkileri arasında ise kişinin öğrenme kabiliyetini, sosyal gelişimini ve iletişim becerisini etkileyen nörogelişimsel bozukluklar, davranış-duygu problemleri ve solunum problemleri yer almaktadır (Mohammadyan vd. 2010).

Tozlara, yüksek fiziksel aktivitelerinin ve yerle temaslarının fazla olması ayrıca beden kitle indekslerinin daha düşük olması nedeniyle en çok çocuklar maruz kalmaktadır (Sofüoğlu 2016). Havadaki kirletici etken maddeler, zamanla çökelip solunabilir tozlarda birikmektedirler. Sınıflarda biriken solunabilir tozların çocuklarda astım krizlerini arttırdığı ya da şiddetlendirdiği, astımlı çocuklarda bronşit belirtilerinin ortaya çıkmasını kolaylaştırdığı bilinmektedir (Sevencan vd. 2011). Okulların iç ve dış ortam hava kirletici seviyeleri, öğrencilerin sağlığını ve dolaylı olarak da öğrenme performanslarını etkilemektedir. Bu nedenle, çocukların gündelik yaşamlarının büyük bir bölümünü geçirdikleri okulların, çevresel kirlilik düzeylerinin incelenmesi oldukça önemlidir (Sofuoğlu 2016).

Evsel ısınmadan kaynaklanan çevresel kirlilik, endüstriyel ve trafik kaynaklı kirlilik ve coğrafi konumu dolayısıyla kirleticilerin bölgeye hapsolması nedeniyle Düzce ilinde çevresel kirliliğin izlenmesi ve sebep olabileceği olumsuz etkilerin araştırılması gerekmektedir. Yerleşim ve endüstri bölgelerinde toplum ve ekosistem üzerinde önemli etkileri olan kirleticilerin izlenmesi ve olası tehlikelere karşı önlemlerin alınmaması halk sağlığı ve ekolojik dengenin sağlanması için bir zorunluluktur.

Düzce İli gelişmekte olan bir ildir. Çevre kirliliğinin çözüme ulaşması için yapılacak planlamalarda, kirliliğinin boyutlarının ve sağlık etkilerinin bilinmesine ihtiyaç vardır. Kirleticilerin insan sağlığı üzerindeki etkileri incelendiğinde çocukların yetişkinlere göre daha fazla risk altında olduğu bilinmektedir. Çalışma kapsamında, Düzce ilinde bulunan 30 ilkokulun iç ve dış ortam solunabilir tozlarında PCB konsantrasyonları belirlenmiştir. Bu kapsamda, alınan tozlardan elde edilen veriler ile Düzce'deki ilkokullardaki solunabilir tozlardaki PCB kirliliğinin boyutları, kaynakları ve bölge genelindeki dağılımın belirlenmesi amaçlanmaktadır. 


\section{Materyal ve Yöntem}

\section{1. Çalışma Alanı}

Düzce ili, Karadeniz Bölgesi’nde yer almakta olup yüzölçümü 2492 km²'dir ve deniz seviyesinden yüksekliği 150 m'dir. Düzce ilinde; Cumayeri, Akçakoca, Çilimli, Gölyaka, Gümüşova, Kaynaşlı, Yığılca ve Merkez ilçe dahil toplam sekiz ilçe bulunmaktadır. İlin genel ekonomik yapısı tarım, ticaret ve kısmen de olsa sanayiye dayanmaktadır. Düzce'ye ait 2019 yılı nüfus sayım sonuçlarına göre toplam 392.166 nüfusun \%66’sı şehir merkezlerinde, \%34'ü ise köylerde yaşamaktadır (URL-1 2019).

İl toprakları, kıyı kesimi dışında ortası çukur, çevresi dağlarla çevrilmiş alanlardan oluşmaktadır. Orta kesimdeki çukur alanda tarımsal üretim açısından büyük önem taşıyan Düzce Ovası yer alır (URL-1 2019). Düzce; İstanbul'u Ankara'ya bağlayan D-100 (E-80) Karayolunun ortasında, İstanbul'a 205 km ve Ankara'ya $241 \mathrm{~km}$ mesafede yer almaktadır. Zonguldak-Karadeniz Ereğlisi-Akçakoca'yı birbirine bağlayan ve Düzce Merkezde D-100 ile birleşen karayolu il merkezinin kuzeyinden geçmektedir. İl merkezinin güneyinden ise TEM Otoyolu geçmektedir. TEM Otoyolu üzerinden Kaynaşlı girişi, 21 km batısında da Gölyaka girişi bulunmaktadır (Özaslan vd. 2001). İl'de 113 km devlet Yolu, $72 \mathrm{~km}$ il Yolu, $41 \mathrm{~km}$ otoyol olmak üzere $226 \mathrm{~km}$, Karayolları 1.Bölge Müdürlüğ̈̈’nün (İstanbul) sorumluluk ağı içerisinde yer alan $12 \mathrm{~km}$ Otoyolu ile birlikte Düzce İlindeki toplam yol uzunluğu 238 km'dir. Devlet ve il yollarının (otoyollar dahil) 196 km'si bitümlü sıcak karışım kaplamalı, 42 km'si sathi kaplamalı yoldur (URL-2 2020).

\section{2. Örnekleme İstasyonlarının Seçimi ve Örneklerin Toplanması}

Çalışmada Düzce ili genelinde ilçeleri de kapsayacak şekilde belirlenen 30 okulun iç ve dış ortamlarından toz örnekleri toplanmıştır. Çalışma kapsamında örneklemelerin yapılabilmesi amacıyla Düzce İl Milli Eğitim Müdürlüğünden Akşemsettin İlkokulu, Avni Akyol İlkokulu, Azmimilli ilkokulu, Beyciler İlkokulu, Beyköy Ortaokulu, Cumhuriyet İlkokulu, Çamköy Fatma Gösterişli İlkokulu, Dokuzdeğirmen İlkokulu, Esenli İlkokulu, Fatih İlkokulu, Gümüşova İlkokulu, Hacıyakup ilkokulu, Hamidiye İlkokulu, Konuralp İlkokulu, Köprübaşı İlkokulu, Namık Kemal İlkokulu, Nasırlı İlkokulu, Nejdet Bıçakcıoğlu İlkokulu, Pakmaya Nimet Pısak İlkokulu, Rıza Malatyalı İlkokulu, Saçmalıpınar İlkokulu, Sancaklar İlkokulu, Sarıçökek İlkokulu, Şerefiye İlkokulu, Şıralık Vatan İlkokulu, Toki Mehmet Akif Ersoy İlkokulu, Yenimahalle İlkokulu, Yeşiltepe İlkokulu, 23 Nisan İlkokulu için gerekli izinler alınmıştır.

Örnekleme yapılan okulların seçiminde kentsel, kırsal, yarı kentsel ve endüstriyel bölgeler dikkate alınmıştır. Endüstriyel bölgeler kırsal ve yarı kentsel bölgelerde bulunduğundan dolayı kırsal-endüstriyel ve yarı kentsel-endüstriyel olarak adlandırılmıştır. Seçilen 30 ilkokuldan 30 iç ortam, 30 dış ortam olmak üzere toplam 60 adet toz numunesi toplanmıştır. Dış ortam tozları okul bahçelerinden süpürge ve faraş yardımıyla toplanmıştır. İç ortam tozları ise hem süpürge ve faraş hem de elektrikli süpürge ile süpürülerek toplanmıştır. Örnekleme noktalarından toplanan toz örnekleri, PCB analizleri için cam şişelerde $-18^{\circ} \mathrm{C}^{\prime}$ de muhafaza edilmiştir.

Çalışmada örnekleme yapılmak üzere seçilen ilkokulların bulunduğu bölgeler kentsel (KNT), kırsal (KRS), yarı kentsel (YK), kırsal-endüstriyel (KRS-E) ve yarı kentsel-endüstriyel (YK-E) bölge olmak üzere 5'e ayrılmıştır. Şekil 1'de yer alan haritada örnekleme noktaları bulundukları bölgenin özelliklerine bağlı olarak farklı renklerde gösterilmiştir.

Bölgesel özelliklerine göre 5'e ayrılan Düzce ilinde kırsal yerleşim alanları, şehir merkezinden ve trafikten uzak, az nüfuslu köyleri ve daha çok yeşillik alanlara yakın bölgeleri temsil etmektedir. Düzce'deki kentsel yerleşim alanları belirlenirken örnekleme noktasının kent merkezi ve yoğun yerleşim yerlerine yakınlığı, sanayi ve diğer hizmetler gibi tarım dışı faaliyetlerin gerçekleştirildiği bölgeler göz önünde bulundurulmuştur. Yarı Kentsel yerleşim alanları, şehir merkezinden uzak fakat yakınından D100, E80 gibi yollar geçen bölgeler olarak tanımlanmıştır. Kırsal ve yarı kentsel bölgelerde yakın konumda endüstriyel alanlar var ise bu noktalarda kırsal-Endüstriyel ve Yarı Kentsel-Endüstriyel olarak tanımlanmıştır. Bu noktalar, Düzce'de bulunan Organize Sanayi Bölgesi (OSB) 1. ve 2. Etap veya fabrikaların yakınında bulunan yerleşim alanlarını temsil etmektedir.

\section{3. Örneklerin Hazırlanması}

Deneysel çalışmalara başlamadan önce, okullardan toplanan numunelerin içerdiği büyük boyutlardaki çöpler dikkatlice numunelerden ayrılmıştır. Daha sonra, numuneler sırasıyla $100 \mu \mathrm{m}$ paslanmaz çelik eleğe konulup elek sallama cihazında elenmiştir. Elekten kaçmış olabilecek saç, kıl, tüy vb. cisimler cımbız ve pens yardımıyla tozların arasından ayıklanmıştır. Tüm numuneler elendikten sonra iç ve dış ortam tozları, amber cam viallere ayrı ayrı konulup etiketlenmiş ve analiz edilmek üzere $-18^{\circ} \mathrm{C}$ derin dondurucuda muhafaza edilmiştir. 


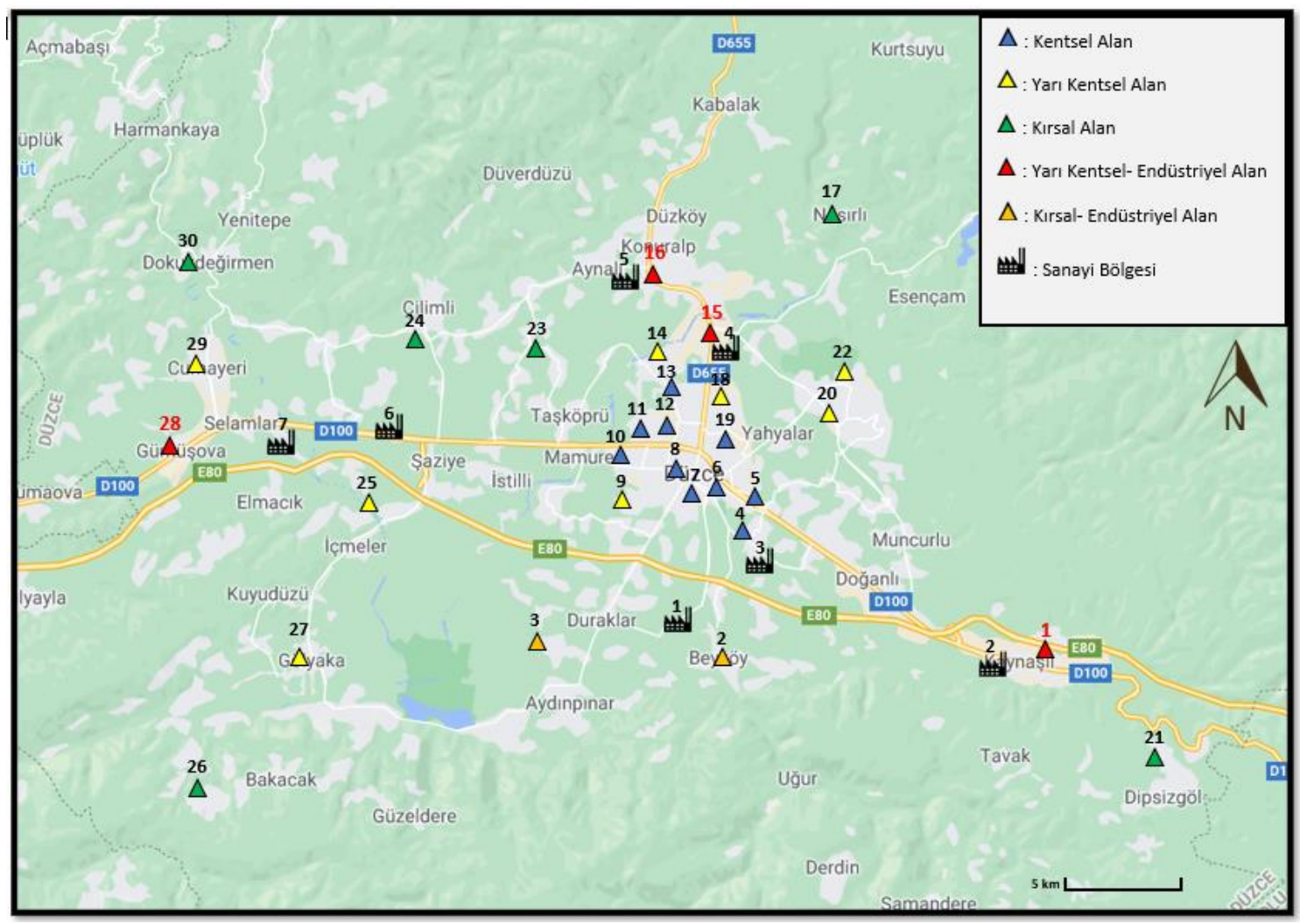

Şekil 1: Örnekleme noktalarının haritada gösterimi

\subsection{PCB Analizleri}

Bu çalışmada EPA öncelikli 209 adet PCB türlerinden çevresel örneklerde en çok bulunan 7 adet indikatör PCB'ye ek olarak 6 adet PCB türü (2,2',5-Trichlorobiphenyl (PCB 18), 2,4,4'- Trichlorobiphenyl (PCB 28), 2,4',5-Trichlorobiphenyl (PCB 31), 2,2',5,5'-Tetrachlorobiphenyl (PCB 52), 2,2',3,5'-Tetrachlorobiphenyl (PCB 44), 2,2',4,5,5'Pentachlorobiphenyl (PCB 101), 2,2',3,4',5',6-Hexachlorobipheny (PCB 149),2,3',4,4',5-Pentachlorobiphenyl (PCB 118), 2,2',4,4',5,5'-Hexachlorobiphenyl (PCB 153), 2,2',3,4,4',5,5'-Heptachlorobiphenyl (PCB 180), 2,2',3,3',4,4',5-

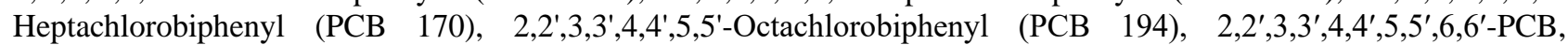
Decachlorobiphenyl (PCB 209) belirlenmiştir. Analizlerde US EPA 8270E (2014), US EPA 3600C (1996), US EPA 3550C (2007), yöntemleri temelinde, iç ve dış ortam tozlarında PCB içeriğinin doğru bir şekilde belirlenebilmesi için laboratuvarda bir dizi çalışmalar gerçekleştirilmiş ve ilgili yöntemler örnek matrisimize uygun olarak modifiye edilmiştir. Laboratuvarda yapılan ön çalışmalar sonucunda belirlenen PCB analiz yöntemi aşağıdaki bölümlerde verilmiştir.

\subsection{Ekstraksiyon ve Ön Zenginleştirme}

Derin dondurucuda saklanan dış ortam toz örneklerinden 5'er gram, iç ortam toz örneklerinden 1'er gram hassas terazide tartılarak 45 ml'lik santrifüj tüplerine konulmuştur. Tartılan her bir örneğe yapılacak işlemler sırasındaki kayıpları belirmek için PAH ve PCB vekil standartları eklenmiş ve 2 saat tüplerin ağzı kapalı şekilde buzdolabında bekletilmiştir. Daha sonra buzdolabında bekletilen örneklere $20 \mathrm{ml}$ 1:1 oranında (Suprasolv) Aseton: Hekzan eklenmiştir. Santrifüj tüplerinde hazırlanan örneklerin kapakları sıkıca kapatılıp parfilm ile iyice sarılarak 1 gece buzdolabında bekletilmiştir. 1 gece bekletilen örnekler, zaman kaybetmeden dolaptan alınıp ultrasonik banyoya konulmuş ve tüplerin 2/3'üne gelecek şekilde saf su doldurulmuştur. Örnekler, ultrasonik banyoda $25^{\circ} \mathrm{C}$ 'yi geçmeyecek şekilde 2 saat ekstrakte edilmiştir.

Ekstraksiyon işleminden sonra örnekler, santrifüj cihazında $3000 \mathrm{rpm}$ hızında $15 \mathrm{dk}$ santrifüjlenmiştir. Santrifüj sonunda üstteki solvent santrifüj tüpünün dibinde biriken tozlara değdirilmeden alınıp numaralandırılmış evaporatör balonlarına aktarılmıştır. Herhangi bir kayıp yaşanmaması için bu işlem $10 \mathrm{ml}$ hekzan eklenerek 2 kez tekrarlanmıştır. Evaporatör balonundaki örnekler, evaporatörde 5 ml'ye uçurulmuş, daha sonra 2 kez hekzan eklenerek işlem tekrarlanmış ve balondaki örnek hekzana alınmıştır. 5 ml'ye uçurulan örnekler, saf azot gazı ile 2 ml'ye uçurularak ön zenginleştirme işlemi tamamlanmıştır. 


\subsection{Clean-Up (Temizleme) ve Son Zenginleştirme}

$\mathrm{Bu}$ çalışmada, dış ve iç ortamlardan toplanan toz örneklerinde 2 farklı clean-up yöntemi kullanılmıştır. Dış ortam toz örneklerinin clean-up işlemi kartuş kullanılarak, iç ortam toz örneklerinin clean-up işlemi ise kolon kullanılarak gerçekleştirilmiştir.

Dış ortam örneklerinin clean-up (temizleme) işleminde, Agilent Technologies marka Bond Elute SI kartuşlar ve vakum manifold aparatı kullanılmıştır. Kartuşları yıkamak amacıyla toplam $25 \mathrm{ml}$ Suprasolv Hekzan kullanılmıştır. Kartuş tam kurumadan ön zenginleştirme aşamasında 2 ml'ye uçurulan örnekler kartuşlara eklenmiştir. Kartuştan PCB'leri almak için toplam $25 \mathrm{ml}$ Suprasolv Hekzan kullanılmıştır.

Clean-up işleminde elde edilen tüm örnekler evaporatörde $5 \mathrm{ml}$ 'ye uçurulmuştur. $5 \mathrm{ml}$ hacimdeki PCB örnekleri saf azot altında $1 \mathrm{ml}$ 'ye uçurulmuştur. Daha sonra örnekler amber renkli viallere alınarak etiketlenmiş ve GC/MS'de analiz edilinceye kadar derin dondurucuda muhafaza edilmiştir.

İç ortam örneklerinin clean-up (temizleme) işlemi, cam yünü, florisil, alümina ve sodyum sülfat içeren kolonlar hazırlanarak gerçekleştirilmiştir. Cam yünü önceden Hekzan ile 1 saat ultrasonik banyoda temizlenmiş ve kurutulmuştur. Kuruyan cam yünü, kapaklı amber bir cam şişeye konularak desikatörde saklanmıştır. Ardından, Florisil $450^{\circ} \mathrm{C}$ 'de 20 saat kül firınında aktive edilmiştir. Alümina $450^{\circ} \mathrm{C}$ 'de 20 saat kül fırınında aktive edilmiştir.

Kolon materyalinin deaktivasyonu için clean-up kolonu hazırlanmaya başlamadan 2 saat önce florisil ve alümina deaktive edilerek desikatörde karanlık ortamda bekletilmiştir. Florisil $\% 5$ oranında, alümina \%1,5 oranında ultra saf su ile deaktive edilmiştir.

Clean-up kolonunun hazırlanması amacıyla cam kolonlar kullanılmıştır. Kolonlar alttan üste doğru, 0,3 gram cam yünü, 1 gram deaktive edilmiş alümina, 1 gram florisil ve 1 gram sodyum sülfat ile doldurulmuştur. Kolon öncelikle 20 $\mathrm{ml}$ hekzan ile temizlenmiştir. Sodyum sülfatın üzeri tamamen kurumadan 2 ml'ye uçurulmuş örnek kolona eklenmiştir. $25 \mathrm{ml}$ Hekzan ile PCB'ler alınmıştır. Clean-up aşamasından sonra PCB balonundaki örnek önce evaporatör ile 5 ml’ye, daha sonra azot altında $1 \mathrm{ml}$ 'ye uçurulmuştur. $1 \mathrm{ml}$ hacmindeki örnekler, etiketlenmiş amber renkli viallere aktarılmıştır. Örnekler GC/MS' de analizlerine kadar $-18^{\circ} \mathrm{C}$ derin dondurucuda muhafaza edilmiştir.

\subsection{Verilerin Kalite Kontrol Çalışmaları}

Yapılan çalışmada PCB analizleri için Agilent 6890 GC/5973MSD cihazı kullanılmıştır. Metot çalışmalarındaki ilk adım GC/MS'de ölçülecek olan bileşenleri cihazda tanımlamak, yüksek hassasiyette ölçülecek sicaklık programını belirlemek ve hassasiyeti arttırmak için GC/MS'de kullanılacak SIM metodu için bileşenlerin m/z değerlerini tanımlamaktır. $\mathrm{Bu}$ amaçla PCB standart çözeltilerinden 0,01 ppm'lik çözeltiler hazırlanmıştır. GC/ECD ve GC/MS cihazları için uygun sıcaklık programları esas alınarak analiz işlemleri gerçekleştirilmiştir.

PCB'lerin her bir örnek içerisindeki miktarlarının belirlenmesi için GC/MS'de her bir kirletici parametrenin kalibrasyonlarının yapılması gerekmektedir. Kalibrasyon çalışmaları 5 noktalı olarak gerçekleştirilmiştir. PCB'lerin ölçülmesinde kullanılan cihaz ve örnek hazırlama yöntemlerinin kalite kontrolü amaciyla metot tayin limitleri, blank örnek analizi, kalibrasyon kontrolü analizleri tekrarlanabilirliği ve geri kazanım çalışmaları yapılmıştır.

GC/MS tayin sınırlarının belirlenmesi için (LOD) her grup için kalibrasyon noktalarının en küçüğü seçilerek 7 kez okutulmuştur. Elde edilen konsantrasyon sonuçlarının standart sapması alındıktan sonra 3 (Student t değeri) ile çarpılarak LOD değerleri elde edilmiştir. Tayin sınırı genellikle gerçek ölçümlerde çok düşük kaldığı için metot ölçümm sınırlarının belirlenmesi gerekir. LOQ (ölçüm sınırı) belirlemek için her grup için kalibrasyon noktalarının en küçüğü seçilerek 7 kez GC-MS'de okutulmuştur. PCB LOQ 0.6 ile 3 ppb arasında bulunmuştur.

Blank örnekleri, örneğin hazırlanmasında analiz sonuçları üzerinde herhangi bir kirlilik olup olmadığını belirlemek için kullanılmıştır. Blank örneği yerine sodyum sülfat kullanılmıştır. Her analiz setinde bir blank kullanılmış ve örneklerle aynı hazırlama yöntemleri uygulanmıştır. Arazi blank örneği için önceden hexan ve asetonla temizlenmiş yüzeye sodyum sülfat dökülmüş ve örnekle aynı şekilde süpürülerek toplanmış, sonrasında laboratuvarda aynı ekstraksiyon clean up işlemleri uygulanmıştır. Elde edilen veriler örnek verilerle karşılaştırılmış ve blank örneklerin günlük örneklere oranları belirlenmiştir. PCB bileşiklerinin çoğu blank örneklerinde görülmemiştir. Çok küçük bir yüzde olarak, bazı PCB türleri, laboratuvar blanklerinde örneklerin \%5'inden az, arazi blanklerinde \%10'dan az oranda ölçülmüştür. Veri analizinde, blank değerler örnek değerlerden çıkarılmıştır. Blank değerlere çok yakın bulunan sonuçlar veri analizinde kullanılmamıştır.

GC/MS sisteminin kalibrasyonunda bir değişiklik olup olmadığını belirlemek ve sistemin arka plan değerlerinde bir artış olup olmadığını görmek için, her 10 örnekte bir kalibrasyon için hazırlanan standartların ve kromatogramlardan elde edilen pik alan değerlerinin ilk kalibrasyon değerleri karşılaştırılmıştır. Alanlar arasında \%30'luk bir fark gözlendiğinde kalibrasyonlar yenilenmiştir. \%50'den fazla fark gözlendiğinde, kolon kesilip, iyon kaynağ1 temizlenmiş ve yeniden kalibre edilmiştir. Sistemler örneklemeden önce temizlendiğinden, örnekleme sırasında parçaların temizlenmesi ve değiştirilmesi gerekmez. Enjektör bölümündeki septum 25 örnekte bir değiştirilmiştir.

GC/MS'de ölçülen örneklerin analizinde bir hata olup olmadığını belirlemek için bazı örneklerde tekrarlanabilirlik çalışmaları yapılmıştır. Bu amaçla, bazı örnekler 5 kez okunmuş ve standart sapmalar belirlenmiştir. Elde edilen verilerde analizlerin tekrarlanabilirliği \%10'un altında bulunmuştur. 
Geri kazanım çalışmaları için iç ve dış ortam toz örneklerine standartlar eklenmiş ve toz örnekleri için uygulanan yöntemlerle aynı şekilde analiz edilmiştir. Duplicate geri kazanım verimleri \%80 ile \%112 arasında değişmiştir. Diğger taraftan, surragate standartların geri kazanım oranları PCB’lerde \%76-98 olarak bulunmuştur.

\subsection{Coğrafi Bilgi Sistemleri Uygulamaları}

Çalışma kapsamında ölçülen kirletici konsantrasyonlarının örnekleme bölgesindeki dağılımının belirlenebilmesi için coğrafi bilgi sistemleri yazılımı (ArcGIS 10.3) kullanılarak kirleticilerin dağılım haritaları oluşturulmuştur. Haritaların oluşturulması için konsantrasyon değerleri, doğal komşuluk interpolasyon (Natural Neighbor Interpolation) yöntemi kullanılarak örnekleme bölgesi için hesaplanmıştır.

\section{Bulgular ve Tartışma}

\subsection{PCB Sonuçlarının Değerlendirilmesi}

$\mathrm{Bu}$ çalışmada örnekleme yapılan okulların iç ve dış ortamlarından alınan toz örneklerinde 2,2',5-Trichlorobiphenyl (PCB 18), 2,4,4'-Trichlorobiphenyl (PCB 28), 2,4',5, -Trichlorobiphenyl (PCB 31),.2,2',5,5'-Tetrachlorobiphenyl (PCB 52), 2,2',3,5'-Tetrachlorobiphenyl (PCB 44), 2,2',4,5,5'-Pentachlorobiphenyl (PCB 101), 2,2',3,4',5',6-Hexachlorobipheny (PCB 149),2,3',4,4',5-Pentachlorobiphenyl (PCB 118), 2,2',4,4',5,5'-Hexachlorobiphenyl (PCB 153), 2,2',3,4,4',5,5'Heptachlorobiphenyl (PCB 180), 2,2',3,3',4,4',5-Heptachlorobiphenyl (PCB 170), 2,2',3,3',4,4',5,5'-Octachlorobiphenyl (PCB 194), 2,2',3,3',4,4',5,5',6,6'-PCB, Decachlorobiphenyl(PCB 209) PCB türleri belirlenmiştir. PCB'lerin çok fazla bileşeni olması nedeniyle, literatürdeki çalışmalarda, daha çok, indikatör PCB türleri (PCB28, PCB52, PCB101, PCB118, PCB138, PCB153, PCB180) belirlenmiştir. Bu PCB türlerine ek olarak bu çalışmada PCB 18, PCB 38, PCB 44, PCB 149, PCB 170, PCB 194 ve PCB 209 türleri de incelenmiştir. 30 farklı örnekleme noktasından toplanan dış ortam ve iç ortam toz örneklerine ait toplam PCB konsantrasyonları ( $\mathrm{PCB}$ ), ortalama, medyan, standart sapma ve minimummaksimum değerleri Tablo 1'de verilmiştir. Tanımlanamayan PCB türleri toplam, ortalama, standart sapma vb. hesaplamalara katılmamıștır. Elde edilen sonuçlarda dış ortam $\Sigma$ PCB konsantrasyonları 0.737-22.307 ng/gr arasında olup, ortalama $3.626 \mathrm{ng} / \mathrm{gr}$ olarak bulunmuştur. İç ortam ЕPCB konsantrasyonları ise 17.17-294.22 ng/gr arasında olup, ortalama 66.89 ng/gr olarak bulunmuştur. D1ş ortam örneklerinde PCB 153, 138, 170, 194, 209 türleri çoğu örnekte belirlenememiştir. İç ortam örneklerinde ise birçok PCB türü belirlenememiş olup, çoğu örnekte tanımlanabilen PCB türleri PCB 18, 52, 44 ve 170'dir.

Şekil 2'de tüm örnekleme noktalarındaki dış ortam ve iç ortam ¿PCB konsantrasyonları verilmiştir. Dış ortam toz örneklerinde en yüksek konsantrasyonlar yarı kentsel endüstriyel özellik gösteren Beyköy İlkokulunda (2 numaralı örnek), en düşük konsantrasyonlar ise kırsal özellik gösteren Yeşiltepe ilkokulunda (21 numaralı örnek) belirlenmiştir.

Beyköy ilkokulunun yakın çevresinde 1. ve 2. OSB'ler bulunmakta ve bu OSB'ler içerisinde tekstil, plastik, kimya, geri dönüşüm, ahşap vb. birçok endüstriyel tesis bulunmaktadır. Dolayısıyla bu noktadaki dış ortamda elde edilen yüksek konsantrasyonlar muhtemelen, bölgedeki endüstriyel emisyonlardan kaynaklanmaktadır.

Dıș ortamda ikinci en yüksek ¿PCB konsantrasyonları kentin tam merkezinde bulunan Fatih ilkokulunda (6 numaralı örnek) bulunmuştur. Fatih ilkokulu tam şehir merkezinde ana yollara çok yakın hem şehir içi hem de şehir dışı trafiğinden yüksek oranda etkilenen ve birçok ticari yapıyla birlikte, konutların bulunduğu bir konumdadır. Dolayısıyla bu noktadaki yüksek PCB konsantrasyonlarının nedeni kentsel emisyonlardır.

İç ortamdan alınan tozlarda ise en yüksek konsantrasyonlar Cumhuriyet İlkokulu (Örnek no: 22) ve Köprübaşı İlkokulundan (Örnek no: 25) elde edilmiştir. Cumhuriyet ilkokulu yarı kentsel bölgede olup yollardan nispeten uzak ve yerleşim sayısı az olan bir bölgedir, öte yandan büyük bir okul olup öğrenci sayısı 500'den yüksektir. Dolayısıyla bu noktadaki yüksek konsantrasyonları daha çok okul içi kaynaklar ve aktivitelerle birlikte, çocukların dışardaki tozları içeriye taşımasıyla oluşan birikimin etkilediği söylenebilir. Köprübaşı ilkokulu ise yarı kentsel bir bölgede olup, okul öğrencisi sadece 14 kişidir. Okula nispeten yakın konumda $(5 \mathrm{~km})$ ve kuzey batısında Gümüşova Sanayi sitesi bulunmaktadır. Bu sanayi sitesinde büyük ölçekli, kimya, plastik, yapı malzemeleri ve alüminyum fabrikaları bulunmaktadır. Dolayısıyla bu noktadaki yüksek PCB konsantrasyonlarının nedeni organize sanayi bölgesinde meydana gelen emisyonların, baskın kuzey batı rüzgarlarıyla bölgeye taşınmasıdır.

Şekil 2'de görüldüğü gibi dış ortam $\Sigma$ PCB seviyeleri ortalama konsantrasyonlardan yüksek ve ortalamaya yakın olan bölgeler çoğunlukla kentsel bölgeler olmakla birlikte, endüstriye yakın olan kırsal ve yarı kentsel bölgelerde de yüksek PCB konsantrasyonları elde edilmiştir $(2>6>4>1>7>9>8>5>10>19>3>20>12>29)$. Diş ortamda $\Sigma$ PCB seviyeleri ortalama konsantrasyonlardan daha düşük olan bölgelerin ise daha çok kırsal ve yarı kentsel alanlar olduğu görülmektedir $(14>28>24>15>13>16>27>11>26>30>18>22>23>25>17>21)$. Öte yandan YK-E bölgelerde bulunan 3 örnekte PCB konsantrasyonları ortalamanın altında kalmıştır.

Şekil 2'de verilen iç ortam $\Sigma$ PCB konsantrasyonlarına göre iç ortam $\Sigma$ PCB seviyeleri ortalama konsantrasyonlardan yüksek ve ortalamaya yakın olan noktalar dış ortamın aksine daha çok YK, YK-E ve KRS-E bölgelerde görülmüştür. KNT ve KRS bölgelerdeki iç ortam konsantrasyonlarının ise genel olarak ortalamadan daha düşük olduğu görülmüştür. 
Dış ortamdan farklı olan bu trend iç ortam kaynaklarının da etkisini ortaya koymuştur. Öte yandan YK-E ve KRS-E bölgelerdeki yüksek PCB konsantrasyonlarına dış ortamdaki yakın konumda bulunan endüstriyel emisyonların da etki ettiği düşünülmektedir.

Şekil 3'de dış ortam $\Sigma$ PCB dağılım haritası verilmiştir. Harita incelendiğinde en yüksek konsantrasyonların 1 . ve 2. OSB'ye yakın kırsal ve yarı kentsel bölgeler olduğu görülmektedir. Öte yandan kent merkezinde de nispeten yüksek konsantrasyonlar görülmektedir. Kent merkezinden uzak kırsal ve yarı kentsel bölgelerde $\Sigma$ PCB konsantrasyonlarının oldukça azaldığı görülmektedir. Düşük konsantrasyonların olduğu bazı bölgelerde yine bazı küçük çaplı endüstriler bulunmaktadır. Ancak bu endüstrilerin etkisi dağılım haritasında gözükmemektedir. Dolayısıyla Düzce'deki okulların dış ortam ГPCB konsantrasyonlarını daha çok 1. ve 2. OSB'deki endüstri kuruluşlarından kaynaklanan emisyonların etkilediği söylenebilir.

Tablo 1: Dış ortam ve lç ortam toz örnekleri PCB konsantrasyonları (ng/gr)

\begin{tabular}{|c|c|c|c|c|c|c|c|c|c|c|c|c|c|c|}
\hline \multicolumn{15}{|c|}{ DIŞ ORTAM } \\
\hline & $\sum_{0}^{\infty}$ & 勿 & $\begin{array}{l}\text { N } \\
0 \\
0\end{array}$ & $\begin{array}{l}\text { J } \\
\text { 己 }\end{array}$ & $e_{0}^{e}-$ & $\sum_{0}^{ \pm} a$ & $\bar{\theta}_{\infty}^{\infty} \infty$ & $\sum_{0}^{n} m$ & $\sum_{0}^{\infty} \infty$ & $\sum_{0}^{\infty} 0$ & 胥 & $\frac{\theta}{0}+$ & $\begin{array}{l}\hat{\tilde{N}} \\
\text { ê } \\
\text { a }\end{array}$ & 点 \\
\hline ORT. & 0,269 & 0,297 & 1,262 & 2,104 & 0,131 & 0,285 & 0,82 & 0,08 & 0,123 & 0,417 & 0,168 & 0,813 & 0,017 & 3,626 \\
\hline $\begin{array}{c}\text { Std } \\
\text { Sapma }\end{array}$ & 0,48 & 0,648 & 0,822 & 3,107 & 2,256 & 0,559 & 1,276 & 0,107 & 0,152 & 0,336 & 0,156 & 0,623 & 0,006 & 5,493 \\
\hline Min & 0,06 & 0,031 & 0,109 & 0,346 & 0,03 & 0,043 & 0,055 & 0,036 & 0,031 & 0,062 & 0,05 & 0,484 & 0,014 & 0,737 \\
\hline $\operatorname{Max}$ & 1,53 & 2,285 & 2,976 & 8,281 & 8,557 & 2,292 & 5,178 & 0,347 & 0,446 & 1,253 & 0,427 & 1,365 & 0,025 & 22,307 \\
\hline KRS ort & 0,065 & 0,084 & 0,693 & ND & 0,055 & 0,121 & 0,204 & 0,058 & 0,118 & 0,473 & ND & 0,484 & 0,019 & 1,26 \\
\hline KNT Ort & 0,489 & 0,52 & 1,171 & 2,312 & 0,164 & 0,808 & 1,991 & 0,347 & 0,101 & 0,401 & 0,102 & 1,365 & ND & 7,126 \\
\hline YK Ort. & 0,065 & 0,162 & 1,363 & 0,909 & 0,097 & 0,259 & 0,691 & 0,036 & 0,115 & 0,377 & ND & ND & 0,014 & 2,57 \\
\hline $\begin{array}{l}\text { YK-E } \\
\text { Ort }\end{array}$ & 0,313 & 0,343 & 0,973 & 8,193 & 0,214 & 0,265 & 1,016 & 0,185 & 0,187 & 0,292 & 0,277 & ND & ND & 3,536 \\
\hline $\begin{array}{c}\text { KRS-E } \\
\text { Ort }\end{array}$ & ND & 1,377 & 2,252 & 7,284 & 8,557 & ND & 2,006 & ND & ND & 0,818 & ND & ND & ND & 12,248 \\
\hline \multicolumn{15}{|c|}{ İÇ ORTAM } \\
\hline $\begin{array}{l}\text { ORT. } \\
\text { Std }\end{array}$ & 9,474 & 0,616 & 23,058 & 20,835 & 21,776 & 208,692 & 22,241 & ND & 5,42 & 2,446 & 5,451 & ND & ND & 66,89 \\
\hline SAPMA & 9.096 & 9,096 & ND & 14,305 & 16,001 & 25,795 & 34,144 & 18,086 & ND & ND & ND & 2,005 & ND & ND \\
\hline Min & 1,138 & 0,616 & 8,947 & 5,64 & 6,007 & 185,941 & 9,665 & ND & 5,42 & 2,446 & 2,512 & ND & ND & 17,173 \\
\hline $\operatorname{Max}$ & 32,291 & 0,616 & 69,487 & 61,474 & 57,55 & 234,228 & 54,425 & ND & 5,42 & 2,446 & 8,893 & $\mathrm{ND}$ & ND & 294,22 \\
\hline KRS ort & 11,796 & 0,616 & 20,891 & 10,713 & ND & ND & ND & ND & ND & 2,446 & 8,552 & ND & ND & 41,892 \\
\hline KNT Ort & 10,815 & ND & 24,405 & 27,723 & ND & ND & 10,272 & ND & 5,42 & ND & 4,717 & ND & ND & 59,862 \\
\hline YK Ort. & 8,237 & ND & 22,938 & 19,921 & 57,55 & 208,692 & 47,655 & ND & ND & ND & 5,789 & ND & ND & 105,47 \\
\hline $\begin{array}{c}\text { YK-E } \\
\text { Ort } \\
\text { KRS-E }\end{array}$ & 6,583 & ND & 23,35 & 22,742 & 13,395 & ND & 16,941 & ND & ND & ND & 5,319 & ND & ND & 86,357 \\
\hline Ort & 14,25 & ND & 23,916 & 42,738 & ND & ND & 18,079 & ND & ND & ND & 4,462 & ND & ND & 46,03 \\
\hline
\end{tabular}



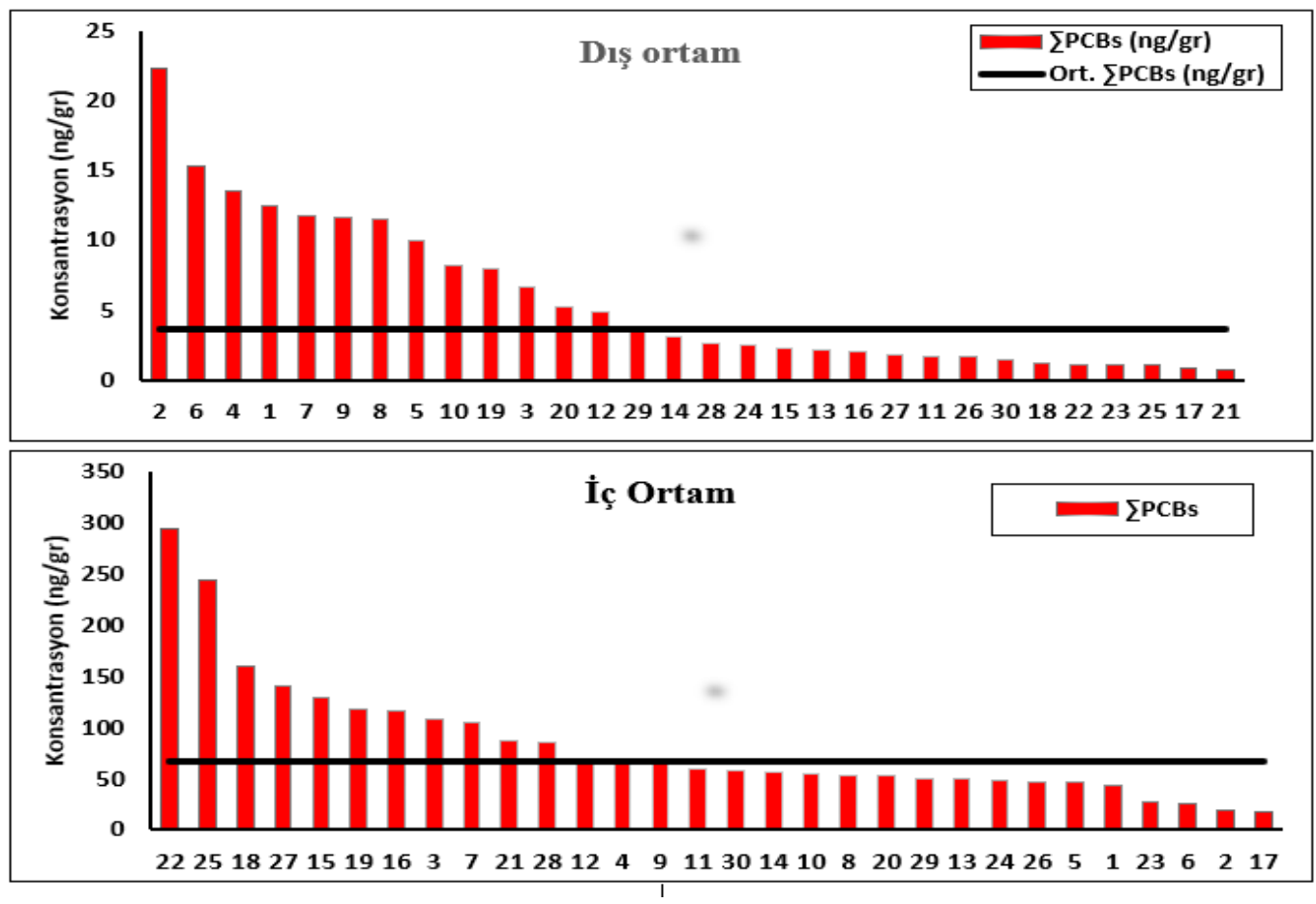

Şekil 2: Iç ve dış ortam toz örneklerinde $\Sigma P C B$ konsantrasyonları (ng/gr)

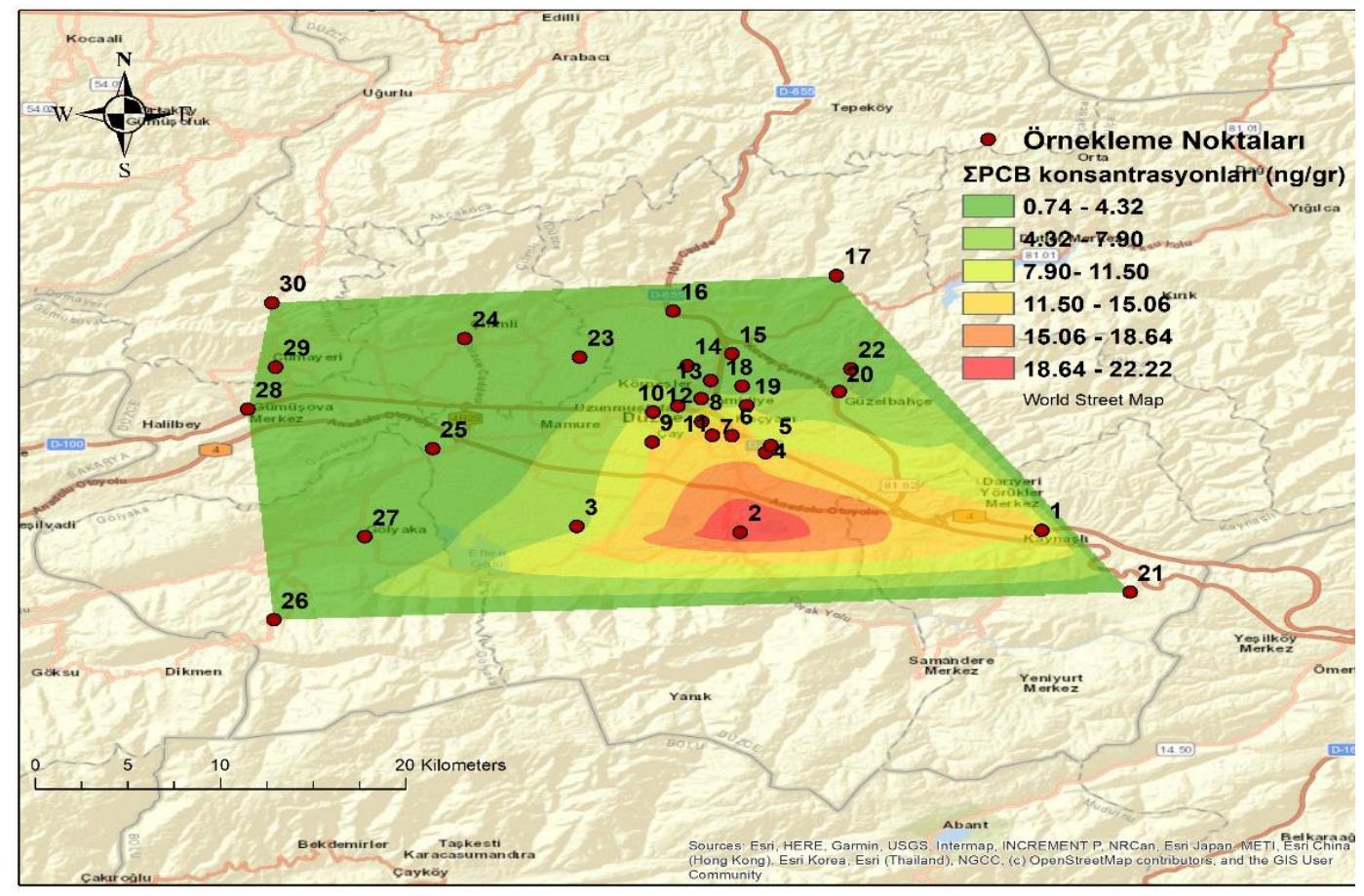

Şekil 3: $\Sigma P C B$ dağılım haritası

Şekil 4'te dış ve iç ortam tozları için, örnekleme bölgesi özelliğine göre elde edilen PCB türevlerinin ortalama konsantrasyonlarının, kırsal bölgelere oranı verilmiştir. Oranlar hesaplanırken sadece belirlenebilen PCB türleri göz önünde bulundurulmuştur. Dış ortam örneklerinde genel olarak tanımlanabilen tüm PCB türlerinin tüm bölgelerde kırsal bölgelerden yüksek olduğu görülmektedir. Kırsal bölgeye en yakın oranların YK bölgeden elde edildiği görülmektedir. Kırsala en yakın oranların PCB52 ve PCB180 türlerine ait olduğu belirlenmiştir.

Şekil 4'te verilen iç ortam oranlarında genel olarak Tüm örnekleme noktalarında $\sum$ PCB konsantrasyonlarının kırsaldan nispeten yüksek olduğu, sadece KRS_E bölgenin kırsal bölgeye çok yakın olduğu görülmektedir. Oranlar, dış ortam oranlarından daha düşüktür. Ayrıca iç ortamda, dış ortama göre biraz daha farklı PCB türleri tanımlanmıştır. 
İç ortamda sadece PCB44'ün diğer bölgelerde kırsal bölgelere göre daha yüksek olduğu görülmektedir. Diğer PCB türleri (PCB 18,52,170) KNT, YK ve YK-E bölgelerde kırsala çok yakın veya daha düşüktür. Bu veriler, iç ortamdaki PCB kirliliğinin dış ortamdan daha çok iç ortamdan kaynaklandığını göstermektedir (Frederiksen vd. 2020). Frederiksen vd. (2020) yaptıkları çalışmada PCB44 bileşiğinin taze emisyonlardan kaynaklandığını belirtmişlerdir. Dolayısıyla iç ortamda PCB 44'ün kırsala göre daha yüksek bulunması iç ortama özgü PCB kaynaklarının kırsal bölgelere daha fazla olmasıyla açılanabilir.
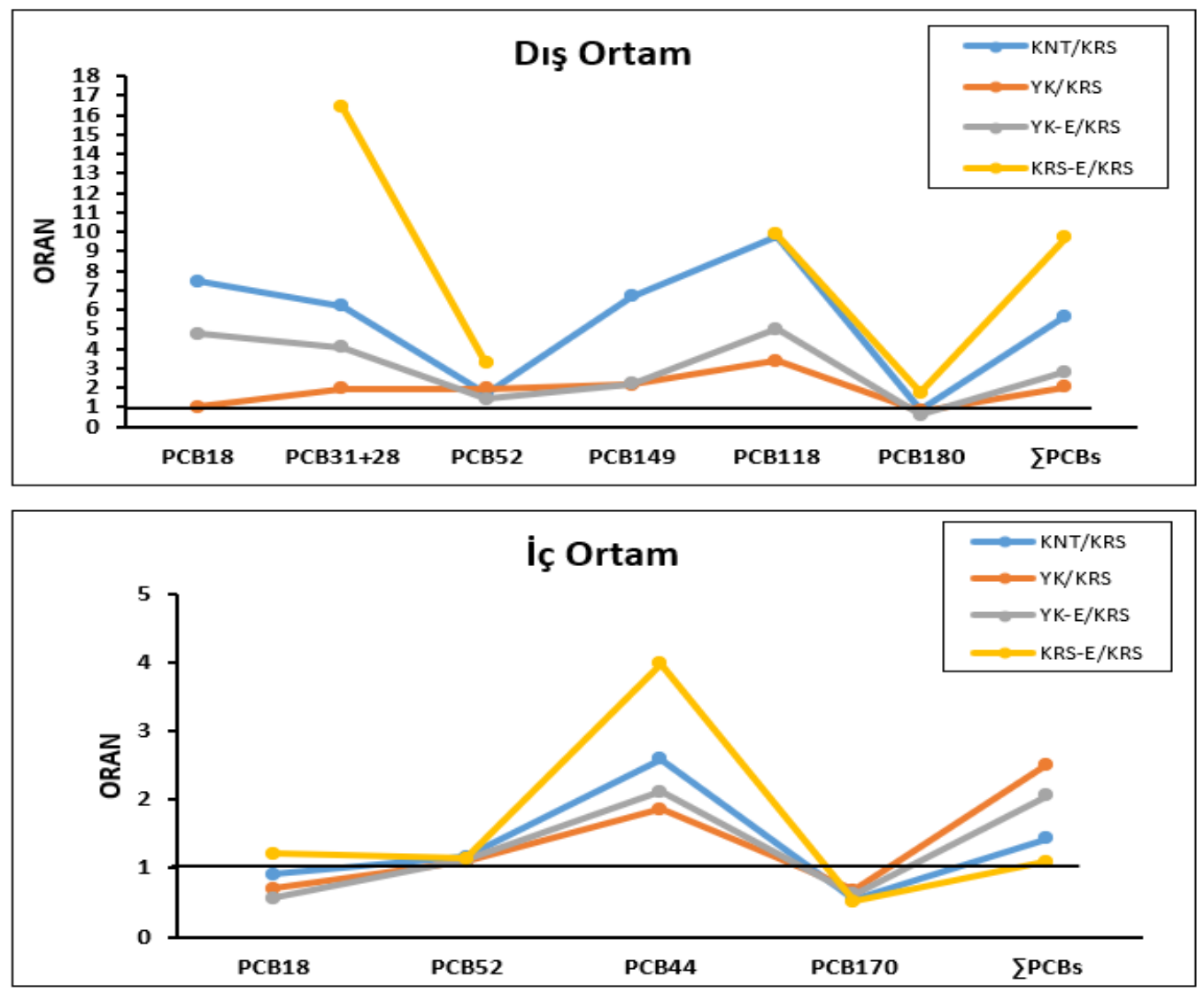

Şekil 4: Dış ve iç ortam tozlarında tüm bölgelerin PCB konsantrasyonlarının kırsal konsantrasyonlara oranı

\section{2. İç Ortam (IO) ve Dış Ortam (DO) PCB İlişkisi}

İç ortamda ve dış ortamda genel olarak farklı PCB türlerinin tanımlanması ve iç ortamda birçok örnekte PCB türlerinin konsantrasyonlarının tanımlama limitlerinin altında ölçülmesi nedeniyle, iç ve diş ortam PCB oranları sadece $\sum$ PCB konsantrasyonlarıyla değerlendirilebilmiştir. $\sum$ PCB konsantrasyonları örneklerde tanımlanabilen PCB türlerinin toplanmasıyla hesaplanmıştır. Şekil 5'te her bir örnek noktası için iç ortam $\sum$ PCB konsantrasyonlarının dış ortama oranı verilmiştir. Şekil 5'te iç ortam konsantrasyonlarının dış ortamdan oldukça yüksek olduğu görülmektedir. IO/DO oranı nispeten küçük olan $(<5)$ örnekleme noktaları daha çok kentsel nokta olmakla birlikte, Yk-E noktalardan birinde de oranlar 1'e yakındır. Dolayısıyla kentsel noktalarda iç ortam $\sum$ PCB kirliliğini iç ortam kaynakları yanında dış ortam kaynaklarının da belli düzeyde etkilediği söylenebilir. Öte yandan IO/DO oranı 1'den küçük tek nokta Krs-E özellikli 2 numaralı Beyköy ilkokuludur. Bu noktada dış ortam $\sum$ PCB konsantrasyonları önceki bölümlerde de açıklandığı gibi en yüksek bulunmuştur. Dolayısıyla bu noktada iç ortam kirliliğine en önemli katkının dış ortamdaki endüstriyel emisyonlar olduğu düşünülmektedir. İç ortam örneklerinde yüksek $\sum$ PCB konsantrasyonları, iç ortam kaynaklarının katkısının daha fazla olduğunu göstermektedir. Özellikle eski yapıların içerisindeki PCB içerikli materyaller, floresanlar vb., elektronik eşyalar vb. iç ortamdaki PCB kaynaklarıdır. Bu materyallerden kaynaklanan PCB emisyonları iç ortamda PCB birikimine neden olmaktadır. Literatürde okullarda yapılan bazı çalışmalarda da benzer sonuçlar bulunmuştur (Dai vd. 2016). 


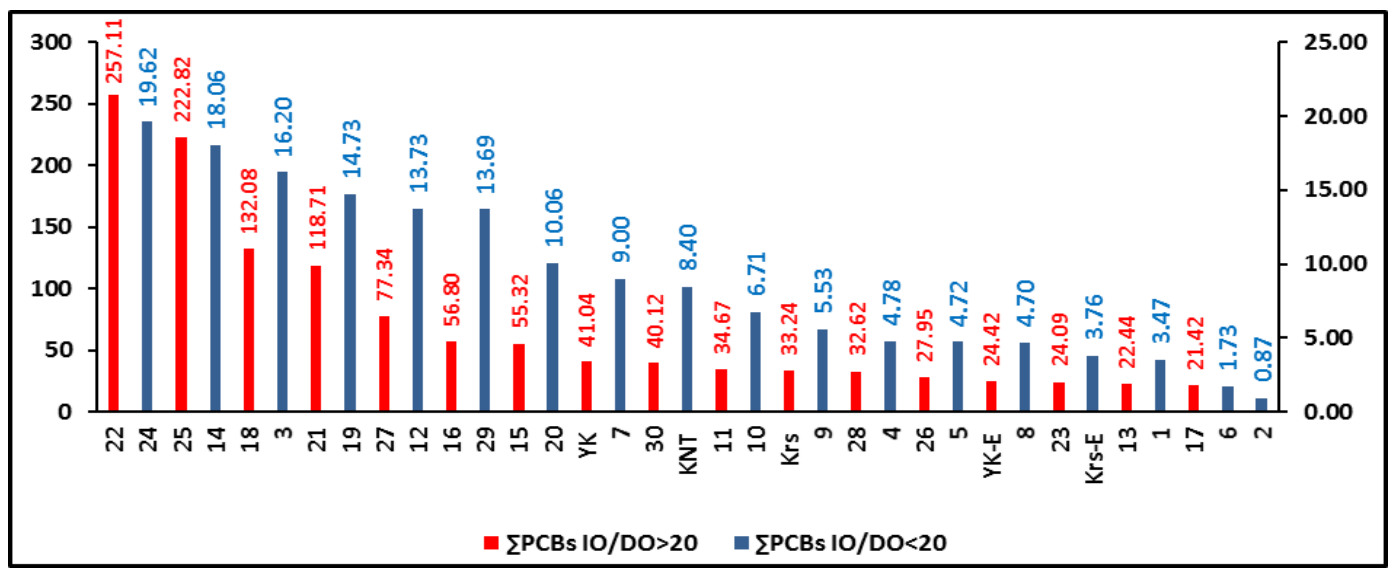

Şekil 5: IO/DO 乏PCB oranları

\subsection{Dış Ortam PCB Profilleri}

Şekil 6'da iç ortam örneklerinde ölçülen PCB türlerinin toplam PCB konsantrasyonlarına katkıları, Şekil 7'de ise bu konsantrasyonların bölgelere göre ortalama dağılımı verilmiştir. PCB'ler klor sayılarına göre gruplandırılmışlardır. TriPCBs 3 klorlu bileşikleri, TetraPCBs, 4 klorlu bileşikleri, PentaPCBs, 5 klorlu bileşikleri, HexaPCBs 6 klorlu bileşikleri, HeptaPCBs, 7 klorlu bileşikleri göstermektedir. PCB’ler genellikle homolog gruplarına göre değerlendirilirler. Örnekleme noktalarındaki PCB homolog gruplarının profillerine baktığımızda dış ortamda en baskın grupların tetra penta grupları olduğunu görmekteyiz. 1-19 grubu kentsel ağırlıklı örnekleme noktalarında tetra ve penta türevlerinin oranı daha fazlayken, 20-30 arasındaki daha çok Krs, YK, Krs-E ve YK-E örneklerinde hepta gruplarının da katkısı görülmektedir. Düşük klorlu gruplar genellikle yapılardan, transformatörlerden vb. kaynaklanırken, yüksek klorlu türevler atık yakılması veya klorlu prosesler gibi endüstriyel emisyonlardan kaynaklanabilmektedir.

Şekil 7'de verilen bölge özelliklerine göre PCB gruplarının katkıları incelendiğinde tüm bölgelerde yaklaşık benzer profiller elde edilmiştir. Öte yandan Krs-E bölgede hexa klorlu gruplar belirlenememiş, YK-E bölgelerde ise tetra klorlu bileşikler daha yüksek oranda hesaplanmıştır. Endüstri emisyonları kendine has kirletici profilleri oluşturabilmektedir. O nedenle bu iki bölgedeki farklılığın endüstriyel emisyonlardan kaynaklandığı söylenebilir.

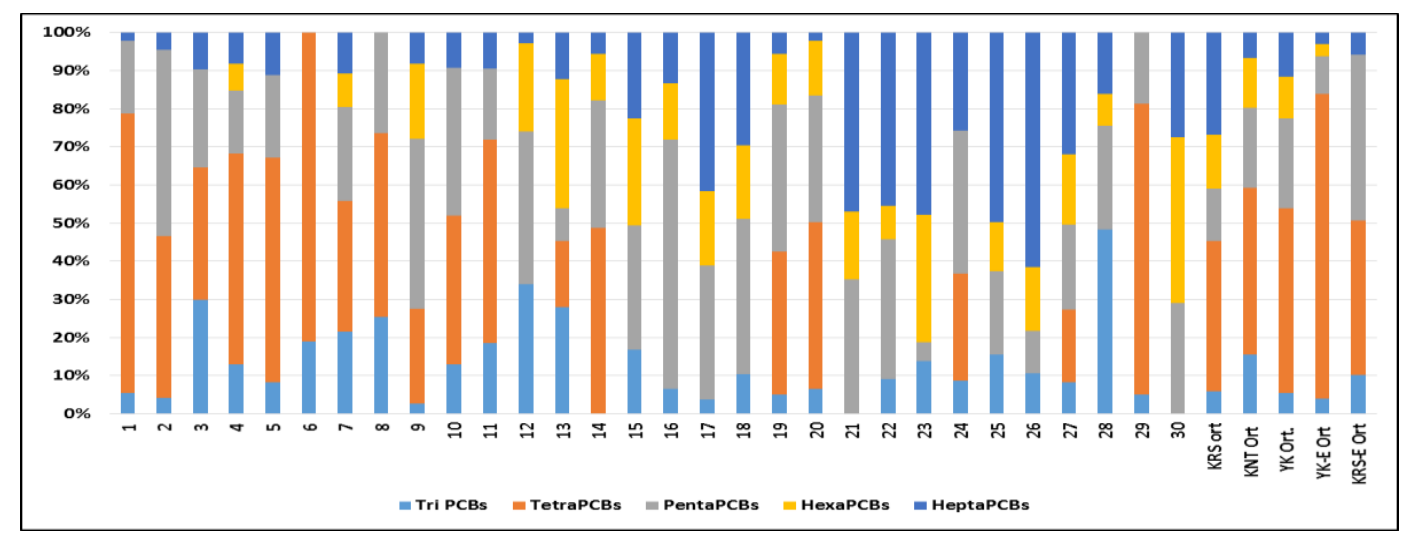

Şekil 6: Dış ortam örnekleme noktalarının PCB profilleri 


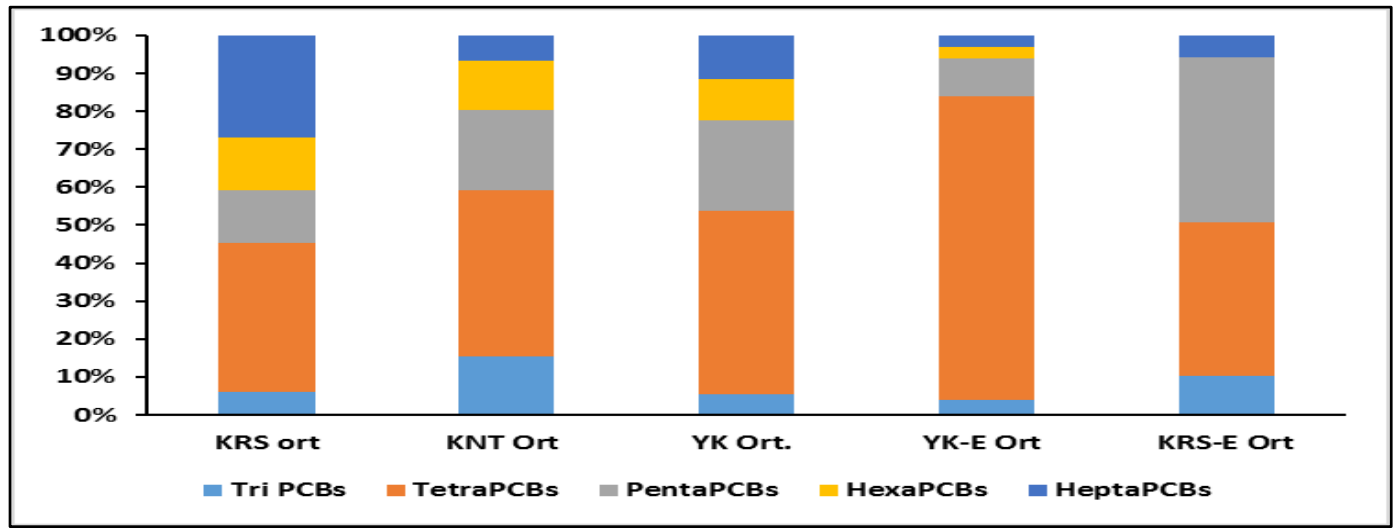

Şekil 7: Dış ortam Bölgesel PCB profilleri

Her bir PCB türü ayrı ayrı değerlendirildiğinde dış ortamda örneklerin çoğunda belirlenen PCB türleri PCB 18, 31+28, 52, 44, 149 ve 180'dir. Bunlar içerisinde en yüksek konsantrasyonlar PCB 52 ve PCB 44'te belirlenmiştir.

\section{4. İç Ortam PCB Profilleri}

Şekil 8. de iç ortam örneklerinde PCB türlerinin toplam PCB konsantrasyonlarına katkıları, Şekil 9'da ise bu oranların bölgelere göre ortalama dağılımı verilmiştir. İç ortam örnekleme noktalarındaki PCB homolog gruplarının profillerine baktığımızda en baskın grupların tri ve tetra grupları olduğunu görmekteyiz. Öte yandan çok sınırlı sayıda örnekte penta gruplarının katkısı da görülmektedir (örnek no:1,9,27,28). Hexa grupları ise çok sınırlı sayıda örnekte baskın olarak görülmekle birlikte (örnek no:22,25) çoğu örnekte belirlenememiştir. Beş veya daha az klorlu PCB bileşikleri ticari karışımlarda ve yapı materyallerinde kullanılmaktadır. Literatürde yapılan çoğu iç ortam çalışmalarında 5 'ten daha az klorlu PCB türleri baskın olarak bulunmuştur. Dolayısıyla iç ortam PCB konsantrasyonlarına daha çok bina içi faktörler etki etmektedir denilebilir (Whitehead vd. 2013). Öte yandan 25 numaralı örnekte yüksek hekza gruplarının görülmesi, Örnekleme bölgesinin, yakınında bulunan Gümüşova OSB içerisindeki alüminyum, plastik vb. tesislerin emisyonlarından etkilendiğinin bir göstergesi olabilir.

Şekil 9'da verilen bölge özelliklerine göre PCB gruplarının katkıları incelendiğinde iç ortam örneklerinde Krs, ve KrsE bölgelerin profillerinin birbirine benzer olup, tetra bileşiklerinin baskın olduğu ve tri ve hepta klorlu. bileşiklerinin de görüldüğü belirlenmiştir. Kentsel bölgede ise yine tetra klorlu PCB türleri baskın olup, tri, penta, hexa ve hepta klorlu PCB türlerinin de katkısı olduğu görülmektedir. Bu bulgular kentsel bölgede iç ortam kaynaklarının yanı sıra dış ortamdaki kaynakların da etkisini göstermektedir.

Her bir PCB türü ayrı ayrı değerlendirildiğinde iç ortamda örneklerin çoğunda belirlenen PCB türleri PCB 18, 52, 44, 170'dir. Bunlar içerisinde en yüksek konsantrasyonlar dış ortamla benzer şekilde PCB 52 ve PCB 44 için belirlenmiştir.

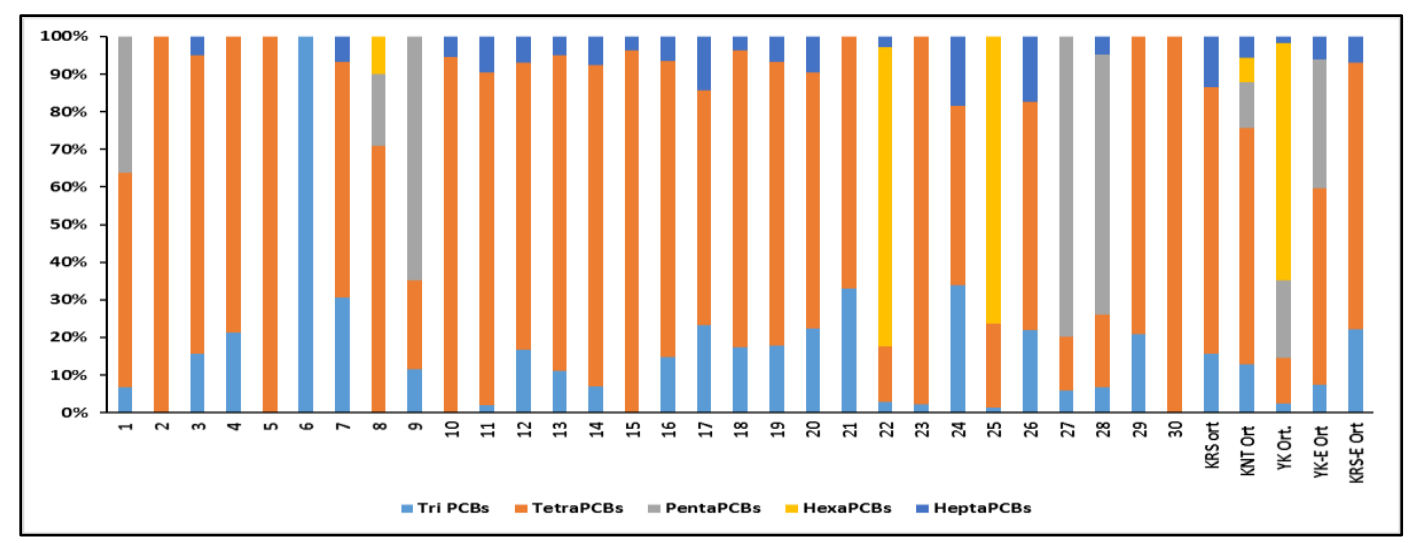

Şekil 8: Iç ortam örnekleme noktalarının PCB profilleri 


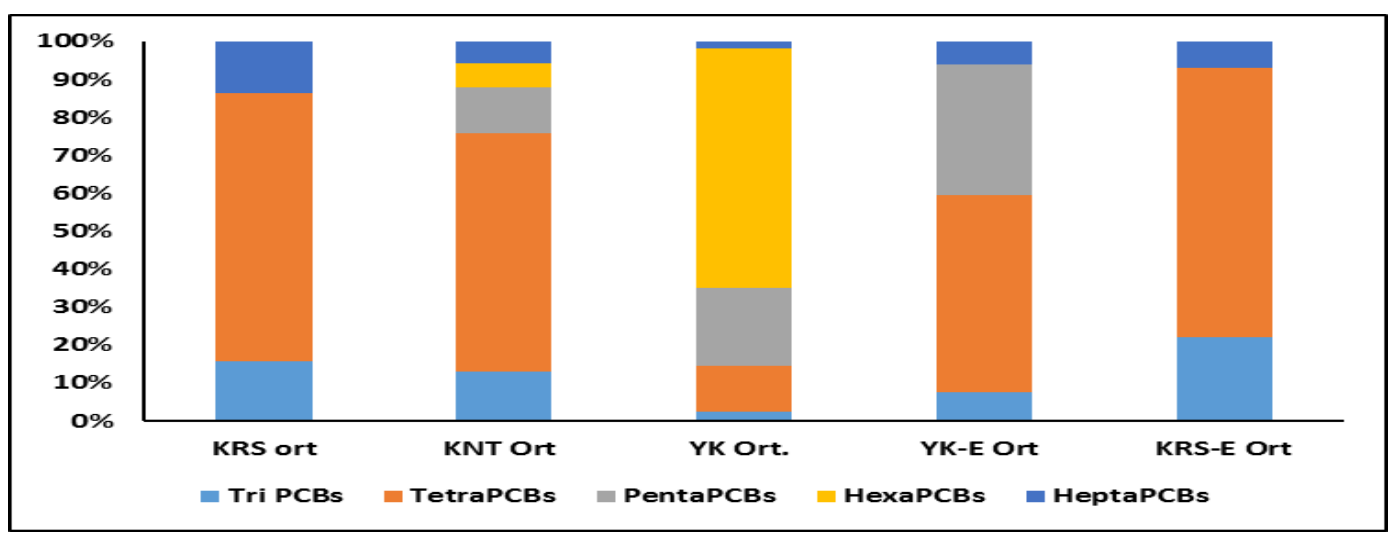

Şekil 9: Iç ortam bölgesel PCB profilleri

\section{Sonuç}

Düzce, hızla gelişen ve çevresel kirliliğin yoğun olarak hissedildiği bir ildir. İlde sanayi, trafik ve konut alanları iç içe geçmiş durumdadır. Ayrıca, ilin coğrafi konumu sebebi ile kaynaktan çıkan kirleticilerin dağılamamakta ve önemli bir risk oluşturmaktadır. Çalışmada, bölgesel bir kirlilik değerlendirmesi yapabilmek ve olası risk durumunu açıklayabilmek için farklı konumlarda ve farklı özelliklere sahip 30 ilkokulun iç ve dış ortamların toz örnekleri toplanmıştır. Yapılan analizlerle toplanan örnekler için PCB konsantrasyonları belirlenmiştir. Her bir kirletici parametre için, kirlilik bölgelerinin izlenmesinde kolaylık sağlayan dağılım haritası oluşturularak ildeki mevcut durum değerlendirilmiş̧tir.

PCB bulgularına göre en yüksek konsantrasyonlar daha çok endüstriye yakın noktalarda elde edilmiştir. İç ortam konsantrasyonları dış ortamdan yüksek bulunmuştur. Birçok bölgede iç ortam PCB kaynaklarına daha çok bina yapısında ve içerisinde kullanılan ve ticari PCB içeren materyaller olduğu ortaya konmuştur. Yüksek PCB konsantrasyonlarının endüstriyel emisyonlarla önemli oranda ilişkisi olduğu görülmüştür. İç ortam PCB konsantrasyonları dış ortam PCB konsantrasyonlarından oldukça yüksek bulunmuş olup, daha çok iç ortam kaynaklarıyla ilişkilendirilmiştir. Kentsel ve endüstriye yakın noktalarda dış ortam PCB kaynaklarının da PCB seviyelerini etkilediği görülmüştür. PCB profilleri iç ve dış ortamda homolog grup olarak daha çok 5 ve 5 'ten az klorlu PCB gruplarının hem iç hem de dış ortamda daha baskın olduğunu göstermiştir. İç ortamda 5'ten fazla klorlu PCB homolog grubu nadiren görülmüştür. Diş ortamda ise özellikle endüstriyel bölgelerde hekza ve hepta klorlu PCB'ler görülmüştür. Bu durum dış ortam endüstri emisyonlarıyla açıklanmıştır. İç ortam ve diş ortam PCB profilleri literatürle uyumlu bulunmuştur.

\section{Teşekkür}

Bu çalışma Düzce Üniversitesi Bilimsel Araştırma Projeleri tarafından desteklenmiştir (Proje no: 2019.06.02.997).

\section{Kaynaklar}

Acosta J.A., Faz A., Kalbitz K., Jansen B., Martinez-Martinez S., (2014), Partitioning of Heavy Metals Over Different Chemical Fraction in Street Dust of Murcia (Spain) as a Basis for Risk Assessment, Journal of Geochemical Exploration, 144, $298-305$.

Aydın M.E., Aydın S., Bedük F., Tekinay A., (2015), Atıksuların Sulamada Kullanımı: Toprak ve Üründe Kalıcı Organik Kirleticiler, Uludağ Üniversitesi Mühendislik Fakültesi Dergisi, 20(2), 99-110.

Barro R., Regueiro J., Llompart M., Garcia-Jares C., (2009), Analysis of Industrial Contaminants in Indoor Air: Part 1. Volatile Organic Compounds, Carbonyl, Compounds, Polycyclic Aromatic Hydrocarbons and Polychlorinated Biphenyls, Journal of Chromatography A, 1216(3), 540-566.

Bayram H., Dikensoy Ö., (2006), Hava Kirliliği ve Solunum Să̆lı̆̆ına Etkileri, Tüberküloz ve Toraks Dergisi, 54(1), 80-89.

Cuci Y., Polat E., (2015), Gaziantep’in Trafik Kaynaklı Hava Kirliliğinin Belirlenmesi, KSU Mühendislik Bilimleri Dergisi, 18(2), 111.

Dai Q., Min X., Weng M., (2016), A review of polychlorinated biphenyls (PCBs) pollution in indoor air environment, Journal of the Air \& Waste Management Association, 66 (10), 941-950.

Frederiksen M., Andersen H., Haug L., Thomsen C., Broadwell S.L., Egsmose E.L., Kolarik B., Gunnarsen L., Knudsen L.E. (2020), $P C B$ in serum and hand wipes from exposed residents living in contaminated high-rise apartment buildings and a reference group, International Journal of Hygiene and Environmental Health, 224, 113430, doi: 10.1016/j.ijheh.2019.113430.

Gül H.K.A., Birgül A., Kurt Karakuş P.B., (2018), Ev Tozunda Bulunan Ağır Metallerin İnsan Sindirim Sisteminin Değişik Basamaklarında Biyolojik Olarak Alınabilirliği, KSÜ Mühendislik Bilimleri Dergisi, 21(3), 235-245.

Khairy M.A., Barakat A.O., Mostafa A.R., Wade T.L, (2011), Multielement Determination by Flame Atomic Absorption of Road Dust Samples in Delta Region, Egypt, Microchemical Journal, 97(2), 234-242. 
Mendell M.J., Heath G.A., (2005), Indoor pollutants and thermal conditions in schools influence student performance? A critical review of the literatüre, Indoor Air, 15(1), 27-52.

Mohammadyan M., Alizadeh-Larimi A., Etemadinejad S., Latif M. T., Heibati B., Yetilmezsoy K., Dadvand P., (2017), Particulate Air Pollution at Schools: Indoor-Outdoor Relationship and Determinants of Indoor Concentrations, Aerosol and Air Quality Research, 17(3), 857-864.

Özaslan M., Erşahin G., Akkahve D., Sabuncu A., (2001), Düzce İli Raporu, Devlet Planlama Teşkilatı, Bölgesel Gelişme ve Yapısal Uyum Genel Müdürlüğü, Yayın No. DPT: 2578, Düzce, 62ss.

Öztürk B., Düzovalı G. (2011), Okullarda Hava Kirliliği ve Sağlık Etkileri, X. Ulusal Teisat Mühendisliği Kongresi, TMMOB Makina Mühendisleri Odas1, 13-16 Nisan, İzmir, ss.1715-1723.

Seyran A., Erişir M., (2008), Poli Klorlu Bifeniller ve Sağlık Üzerine Etkileri, Fırat Üniversitesi Sağlı Bilimleri Dergisi, 22(1), 3440.

Sevencan A.C., Sevencan F., Vaizoğlu S., Güler Ç., (2011), Ankara'da Bir İlköğretim Okulunun İ̧̧ ve Dış Çevresel Özelliklerinin Değerlendirilmesi, Genel Tip Dergisi, 21(1), 11-15.

Sofuoğlu S.C., (2016), İç Hava Kirleticileri ve İnsan Sağllğıına Etkileri, Tesisat Mühendisliği, 153, 33-44.

URL-1, (2020), Düzce İl Tarım ve Orman Müdürlüğü Faaliyet Raporu 2019, https://duzce.tarimorman.gov.tr/Menu/21/FaaliyetRaporu [Erişim 16 Kasım 2020].

URL-2, (2020), Ulaşım, T.C. Düzce Valiliği, http://www.duzce.gov.tr/ [Erişim 16 Kasım 2020].

U.S. EPA., (1996), Method 3600 (SW-846): Cleanup, Washington, DC.

U.S. EPA., (2007), SW-846 Test Method 3550C: Ultrasonic Extraction, Washington, DC.

U.S. EPA., (2014), Method 8270E (SW-846): Semivolatile Organic Compounds by Gas Chromatography/ Mass Spectrometry $(G C / M S)$, Washington, DC.

Whitehead T, Metayer C, Buffler P, Rappaport SM., (2011), Estimating exposures to indoor contaminants using residential dust, J Expo Sci Environ Epidemiol, 21, 549-64.

Whitehead T.P., Brown F.R., Metayer C., Park J.S., Does M., Dhaliwal J., Petreas M.X., Buffler P.A., Rappaport S.M., (2013), Polychlorinated Biphenyls in Residential Dust: Sources of Variability, Environmental Science \& Technology, 48(1), $157-164$. 